\title{
UPAYA GURU DALAM KEBERHASILAN BELAJAR SKI SISWA DI MTS NEGERI 3 PAMEKASAN (SUMBER BUNGUR)
}

\author{
${ }^{1}$ Ach. Laily, ${ }^{2}$ Mariatul Qibtiyah Harun AR \\ 1, 2 Institut Agama Islam Negeri Pamekasan \\ ${ }^{1}$ mohlailymubarok@gmail.com, ${ }^{2}$ mariatul_q@gmail.com
}

\section{ABSTRACT}

This research uses a qualitative approach with descriptive type. Sources of data obtained through interviews, observation and documentation. The information is the ranks of caregivers, religious teachers, guardians of students and students. The results showed that (1) the efforts made by the teacher in improving the learning success of SKI students of MTs Negeri 3 Sumber Bungur Pakong Pamekasan, among others, were to make a plan for the implementation of learning, mastery of subject matter, selection of appropriate and varied learning methods, use of media and resources learning, conducting evaluations, giving assignments, holding directives and providing assistance to students by always solving problems faced, (2) supporting factors of teacher efforts in the success of students learning SKI is the strong will of students to learn, and factors inhibiting the efforts of teachers in the success of student SKI learning is the limited facilities and infrastructure, such as supporting books in the school library as a source of learning for students, the limited learning media, and the low level of professionalism of SKI teachers.

\section{ABSTRAK}

Penelitian ini menggunakan pendekatan kualitatif dengan jenis deskriptif. Sumber data diperoleh melalui wawancara, observasi dan dokumentasi. Informannya adalah jajaran pengasuh, ustadz, wali santri dan santri. Hasil penelitian menunjukkan bahwa (1) upaya yang dilakukan guru dalam meningkatkan keberhasilan belajar SKI siswa MTs Negeri 3 Sumber Bungur Pakong Pamekasan, di antaranya adalah melakukan penyusunan rencaa pelaksanaan pembelajaran,penguasaan materi pelajaran, pemilihan metode pembelajaran secara

\section{ARTICLE HISTORY \\ Received 10 Pebruari 2021 \\ Revised 19 Maret 2021 \\ Accepted 22 Maret 2021 \\ KEYWORDS \\ Teacher, Learning Success, History of Islamic Culture.}


tepat dan variatif,pemanfaatan media dan sumber belajar, pelaksanaan evaluasi,memberikan tugastugas, mengadakan pengarahan-pengarahan dan memberikan bantuan kepada siswa dengan senantiasa memecahkan permasalahan permasalahan yang dihadapi, (2) faktor penunjang upaya guru dalam keberhasilan belajar SKI siswa adalah adanya kemauan kuat siswa untuk belajar, dan faktor penghambat upaya guru dalam keberhasilan belajar SKI siswa adalah terbatasnya sarana dan prasarana, seperti buku-buku penunjang yang ada di perpustakaan sekolah sebagai sumber belajar bagi siswa, terbatasnya media pembelajaran, dan rendahnya tingkat profesionalitas guru SKI.

\section{PENDAHULUAN}

Pendidikan mempunyai peranan penting dalam rangka pengembangan sumber daya manusia.Terutama di Indonesia sekarang ini, krisis moral sudah mulai terjadi di mana-mana. Pendidikan adalah salah satu sarana pembentukan manusia ke arah yang lebih baik. Walaupun hal itu tidak sepenuhnya menjadi tanggung jawab sebuah pendidikan, namun dengan usaha dan kerja keras bukan tidak mungkin pendidikan dapat menjadi wadah yang baik jika penanaman pengetahuan, sikap dan keterampilan juga baik.

Ada banyak tokoh pada pelaksanaan pendidikan namun ada satu yang paling utama yaitu guru. Guru menurut UUD Guru dan Dosen adalah pendidik professional dengan tugas utama mendidik, mengajar, membimbing, mengarahkan, melatih, menilai dan mengevaluasi peserta didik pada pendidikan anak usia dini jalur pendidikan formal, pendidikan dasar dan menengah¹.

Guru adalah unsur manusiawi dalam pendidikan. Guru adalah figur manusia sumber yang menempati posisi dan memegang peranan penting dalam pendidikan. Guru pada dasarnya adalah orang yang memikul tanggungjawab untuk menimbang peserta didik. Guru sebagai pelaku utama

\footnotetext{
${ }^{1}$ Undang-Undang RI No. 14 Tahun 2005 Tentang Guru dan Dosen Bab I Pasal I
} 
dalam penerapan program pendidikan di sekolah memiliki peran yang sangat penting dalam mencapai tujuan pendidikan yang diharapkan. ${ }^{2}$ Dalam proses belajar mengajar, guru mempunyai tugas untuk mendorong, membimbing, dan mencapai tujuan. Guru mempunyai tanggung jawab untuk melihat segala sesuatu yang terjadi dalam kelas untuk membantu proses perkembangan anak.

Kedudukan guru sebagai pendidik mempunyai peranan yang sangat penting dalam proses belajar mengajar, salah satunya adalah sebagai manajer atau pengelola kelas. Guru sebaiknya mampu menjadi pengelola kelas yang baik, karena kelas adalah tempat berkumpulnya semua siswa dalam rangka menerima bahan pelajaran dari guru. Menurut Djamarah dalam setiap proses pengajaran sebaiknya direncanakan dan diusahakan oleh guru supaya terhindar dari kondisi yang merugikan (usaha pencegahan), dan kembali kepada kondisi yang optimal apabila terjadi hal-hal yang merusak, yang disebabkan oleh tingkah laku siswa di dalam kelas (usaha kuratif) ${ }^{3}$

Dalam penelitian ini, peneliti memilih Guru Sejarah Kebudayaan Islam sebagai obyek penelitian karena secara umum yang peneliti temukan di lokasi penelitian yaitu MTsN 3 Sumber Bungur Pamekasan ditemukan hal-hal sebagai berikut: pertama, masih banyaknya guru yang mengajar dengan metode yang monoton. kedua, karakteristik materi pelajaran SKI yang berupa hafalan masih dilakukan siswa. ketiga, minat belajar siswa terhadap mata pelajaran SKI masih terbilang rendah dan yang keempat masih banyak siswa yang tidak mendengarkan gurunya karena bosan dengan materi yang diajarkan. Hal ini yang menjadi alasan peneliti ingin menggunakan mata pelajaran SKI sebagai bahan penelitian dengan alasan yang telah disebutkan.

Berdasarkan latar belakang yang telah dijelaskan diatas maka penulis bermaksud mengadakan penelitian tentang “Upaya Guru Dalam Keberhasilan

\footnotetext{
2 Syamsu Yusuf \& Nani Sugandhi, Perkembangan Peserta Didik Cetakan ke-3 (Jakarta: Rajawali Press.2012), hlm. 139.

3 Syaiful Bahri Djamarah, Guru dan Siswa dalam Interaksi Edukatif (Jakarta: Rineka Cipta, 2005), hlm. 144.
} 
RABBANI

Belajar Siswa pada Mata Pelajaran Sejarah Kebudayaan Islam di MTs Negeri 3 Sumber Bungur Pakong Pamekasan. "

\section{METODE PENELITIAN}

Dalam sebuah penelitian kita mengenal dua pendekatan yakni pendekatan secara kuantitatif dan pendekatan secara kualitatif. Dalam penelitian ini, saya sebagai peneliti menggunakan pendekatan yang kedua, yaitu pendekatan secara kualitatif, penelitian dengan pendekatan kualitatif menekankan analisis proses berpikir secara induktif yang berkaitan dengan dinamika hubungan antarfenomena yang diamati, dan senantiasa menggunakan logika ilmiah.

Penelitian ini dilakukan untuk mengetahui upaya Guru Mata Pelajaran SKI dalam keberhasilan belajar siswa pada Mata Pelajaran SKI di MTs Negeri Sumber Bungur Pakong Pamekasan. Data yang dikumpulkan pada penelitian deskriptif yakni mengambil bentuk kata-kata atau gambar daripada angkaangka.Hasil peelitian tertulis berisi kutipan-kutipan dari data untuk mengilustrasikan dan menyediakan bukti presentasi.Data tersebut mencakup transkip wawancara, catatan lapangan, fotografi, videotape, dan lain-lain. ${ }^{4}$

Dalam penelitian ini, peneliti mengambil lokasi di MTs Negeri 3 (Sumber Bungur) Pamekasan. Alasan peneliti menjadikan MTs Negeri 3 (Sumber Bungur) Pamekasan karena adanya kesesuaian fenomena di lapangan dengan judul penelitian ini sekaligus lokasi penelitiannyapun mudah dijangkau dan bisa mendaptkan data penelitian dengan mudah meskipun tetap dengan prosedural yang diberlakukan di lembaga.

Sumber data utama dalam kualitatif adalah kata-kata dan tindakan selebihnya adalah data tambahan seperti dokumen dan lain-lain.Berkaitan dengan hal itu, pada bagian ini sumber data dapat diperoleh melalui data primer dan data sekunder. Data primer diperoleh dari sumber data yang bersifat mentah atau belum diolah merupakan hasil dari pengamatan dan

\footnotetext{
${ }^{4}$ Emzir, Metodologi Penelitian Kualitatif Analisis Data (Jakarta: PT RajaGrafindo Persada, 2010), hlm. 3.
} 
wawancara. Sedangkan data sekunder diperoleh melalui sumber tertulis seperti buku, majalah ilmiah, sumber dari arsip, dokumen pribadi dan resmi, foto/rekaman handycam serta data statistik yang berhubungan dengan penelitian yang dilakukan. ${ }^{5}$

Adapun dalam penggalian data, peneliti menggunakan 3 macam tekhnik diantaranya adalah wawancara, observasi atau pengamatan dan juga dokuemntasi. Sedangkan dalam proses analisis data terdiri dari tiga tahapan yang meliputi pertama, reduksi data merupakan kegiatan merangkum, memilih hal-hal pokok, memfokuskan pada hal-hal yang penting, dan mencari tema dan polanya. Data yang telah direduksi akan memberikan gambaran lebih jelas dan memudahkan untuk melakukan pengumpulan data.

Kedua, Pemaparan data, yaitu setelah data direduksi langkah selanjutnya yaitu penyajian atau pemaparan data. Pemaparan data ini dimaksudkan untuk memilih data yang sesuai dengan kebutuhan penelitian. Ketiga, Penarikan kesimpulan merupakan hasil penelitian yang menjawab fokus penelitian berdasarkan hasil analisis data. Simpulan disajikan dalam bentuk deskriptif objek penelitian dengan berpedoman pada kajian penelitian. ${ }^{6}$

\section{HASIL DAN PEMBAHASAN}

\section{Upaya guru dalam meningkatkan keberhasilan belajar SKI siswa MTs} Negeri 3 Sumber Bungur Pakong Pamekasan

Dalam pengertian umum, orang tidak mengalami kesulitan dalam menjelaskan siapa guru dan sosok guru. Dalam pengertian ini, makna guru selalu dikaitkan dengan profesi yang terkait dengan pendidikan anak di sekolah, di lembaga pendidikan, dan mereka yang harus menguasai bahan ajar yang terdapat dalam kurikulum. Secara umum, baik dalam pekerjaan ataupun

\footnotetext{
${ }^{5}$ Basrowi \& Suwandi, Memahami Penelitian Kualitatif (Jakarta: PT Rineka Cipta, 2008), hlm.169174.

${ }^{6}$ Imam Gunawan, Metode Penelitian Kualitatif Teori EPraktek (Jakarta: Bumi Aksara, 2013), hlm. 210-212.
} 
sebagai profesi, guru selalu disebut sebagai salah satu komponen utama pendidikan yang sangat penting.

Guru merupakan orang dewasa yang bertanggung jawab memberi pertolongan pada anak didiknya dalam perkembangan jasmani dan rohaninya, agar mencapai tingkat kedewasaan,mampu berdiri sendiri,dan memenuhi tingkat kedewasaan,mampu mandiri dalam memenuhi tuganya sebagai hamba dan khalifah Allah SWT ${ }^{7}$

Sebagaimana hasil penelitian yang dilakukan oleh peneliti baik malalui wawancara, observasi ataupun dokumengtasi didapatkan bahwa Guru SKI di Negeri 3 Sumber Bungur Pamekasan telah melakukan berbagai upaya dalam keberhasilan belajar SKI siswa dengan berupa memfungsikan kedudukannya secara optimal, baik sebagai pengajar, pendidik, maupun sebagai pembimbing.

Sebagai pengajar, guru melakukan pengelolaan pembelajaran secara baik, seperti melakukan penyusunan rencana pelaksanaan pembelajaran, penguasaan materi pelajaran, pemilihan metode mengajar, pemanfaatan media dan sumber belajar, dan pelaksanaan evaluasi. Guru juga memberikan tugastugas kepada siswa pada setiap akhir pembelajaran, baik yang dikerjakan di sekolah maupun di rumah.

Sebagai pendidik, guru mengadakan pengarahan-pengarahan terhadap perilaku siswa, yakni dari perilaku yang tidak baik ke arah perilaku yang baik, dengan tujuan agar siswa dapat belajar secara baik dan memperoleh hasil belajar Sejarah yang optimal.

Sebagai pembimbing, guru memberikan bantuan kepada siswa dengan senantiasa memecahkan permasalahan-permasalahan yang dihadapi, baik permasalahan pribadi, keluarga, maupun kesulitan-kesulitan belajar.

Dengan demikian, maka dapat dikatakan bahwa dalam melakukan upaya peningkatan keberhasilan proses pembelajaran khususnya pada materi SKI guru mampu menempatkan dirinya sebagai seorang pengajar, pendidik

\footnotetext{
${ }^{7}$ Abdul Mujib, Ilmu Pendidikan Islam (Semarang: Prenada Kencana, 2006), hlm. 87.
} 
dan pembimbing sekaligus juga memiliki kemampuan dalam menjalankan ketiga peran tersebut dalam proses kegiatan pembelajaran SKI .

\section{Faktor penunjang upaya guru dalam keberhasilan belajar SKI siswa Madrasah Tsanawiyah Negeri 3 Sumber Bungur Pakong Pamekasan}

Dalam berupaya mewujudkan keberhasilan belajar SKI siswa sudah pasti banyak hal yang menjadikan faktor penunjang yang dijumpai oleh guru . faktor ini sudah pasti akan menjadi modal utama bagi guru dalam rangka mewujudkan keberhasilan siswa secara utuh dalam mempelajari materi SKI. Setidaknya dalam hal ini ada dua hal yang menjadi faktor penunjangnya, yaitu pertama faktor yang dimunculkan oleh guru berupa kreativitas guru dalam dalam pembelajaran

Kreativitas merupakan suatu proses yang melahirkan sesuatu yang baru baik berupa gagasan, maupun karya nyata, metode ataupun produk baru yang digunakan oleh seseorang dalam memecahkan suatu masalah. Kreativitas merupakan hal yang sangat penting dalam pembelajaran, dan guru dituntut untuk mendemonstrasikan dan menunjukan proses kreativitas tersebut. ${ }^{8}$

Kreativitas guru dalam pembelajaran berkaitan dengan ketrampilan pemilihan penggunaan media, metode, strategi serta pendekatan yang digunakan dalam proses pembelajaran. Pemilihan ini tentunya dengan diandasi pemahaman guru tentang kondisi dan potensi peserta didik, sehingga dalam penggunaannya bisa tepat sasaran.

Sedangkan yang kedua adalah faktor yang dimunculkan oleh siswa berupa kemauan kuat dan semangat yang cukup tinggi dalam mempelajari materi-materi SKI. Hal ini tentu saja menjadi hal yang sangat penting sekaligus menjadi penyempurna bagi guru dalam upayanya mewujudkan keberhasilan siswa dalam belajar SKI. Sebab, akan dirasa sangat sulit baginya jika tidak ada dorongan yang kuat dari peserta didik untuk belajar. Minat belajar siswa

8 E. Mulyasa, Menjadi Guru Profesional (Bandung: PT. Remaja Rosda Karya, 2013), hlm. 51. 
tumbuh dari kondisi pembelajaran yang bervariatif dan tidak membosankan. Pembelajaran yang bervariatif akan mengurangi rasa jenuh peserta didik dalam mengikuti pembelajaran. Sehingga ada respon positif dan minat belajar dari peserta didik dalam mengikuti pembelajaran khususnya pada pelajaran SKI.

\section{KESIMPULAN}

Berdasarkan pada uraian sebagaimana di atas, maka dapat disimpulkan bahwa upaya guru dalam mewujudkan keberhasilan belajar SKI siswa di MTs Negeri 3 Sumber Bungur Pamekasan adalah memfungsikan kedudukannya secara optimal, baik sebagai pengajar, pendidik, maupun sebagai pembimbing. Sebagai pengajar, guru melakukan pengelolaan pembelajaran secara baik, seperti melakukan penyusunan program pembelajaran, penguasaan materi pelajaran, pemilihan metode mengajar dan lain sebagainya. Sebagai pendidik, guru mengadakan pengarahan-pengarahan terhadap perilaku siswa. Sedangkan Sebagai pembimbing, guru memberikan bantuan kepada siswa dengan senantiasa memecahkan permasalahan-permasalahan yang dihadapi, baik permasalahan pribadi, keluarga, maupun kesulitan-kesulitan belajar. Adapun faktor penunjang dari upaya guru dalam mewujudkan keberhasilan belajar SKI siswa di MTs Negeri 3 Sumber Bungur Pamekasan adalah kreatifitas guru SKI dan kemauan atau semangat yang tinggi dari peserta didik dalam belajar SKI.

\section{DAFTAR PUSTAKA}

Djamarah , Syaiful Bahri. Guru dan Siswa dalam Interaksi Edukatif. Jakarta: Rineka Cipta, 2005.

Emzir. Metodologi Penelitian Kualitatif Analisis Data. Jakarta: PT Raja Grafindo Persada, 2010

Gunawan, Imam. Metode Penelitian Kualitatif Teori EPraktek. Jakarta: Bumi Aksara, 2013.

Mujib, Abdul. Ilmu Pendidikan Islam. Semarang: Prenada Kencana, 2006 
Mulyasa, E. Menjadi Guru Profesional. Bandung: PT. Remaja Rosda Karya, 2013.

Nani Sugandhi, Syamsu Yusuf. Perkembangan Peserta Didik, Cetakan ke-3. Jakarta: Rajawali Press. 2012.

Suwandi, Basrowi. Memahami Penelitian Kualitatif. Jakarta: PT Rineka Cipta, 2008.

Undang-Undang RI No. 14 Tahun 2005 Tentang Guru dan Dosen Bab I Pasal I 